\title{
MINIMUM WAGES AND TEEN'S UNEMPLOYMENT RATES
}

\section{Kwang Woo (Ken) Park, Minnesota State University, Minnesota, U.S.A.} Amadou Cisse, Minnesota State University, Minnesota, U.S.A.

\author{
dx.doi.org/10.18374/JIBE-19-3.1
}

\begin{abstract}
There have been a lot of arguments on the real effect of minimum wages on teenagers, non-educated and low-skilled workers. Even though minimum wages should be used as a factor increasing the economic well-beings of low-skilled workers, many of the recent studies showed that a substantial portion of low-skilled worker's jobs are negatively affected by the increase in minimum wage. In this sense, this paper attempt to identify the real effects of changes in minimum wages on low-skilled workers by looking into 50 U.S. states panel data. The empirical findings show that an increase in teenagers' unemployment is caused by a minimum wage hike.
\end{abstract}

Keywords: Minimum Wages, Unemployment Rates, Teen's Unemployment Rates, Error Correction Model (ECM), Pooled Autoregressive Distribution Lag (ARDL) 